\title{
Economic Consequences of Adopting Local Spatial Development Plans for the Spatial Management System: The Case of Poland
}

\author{
Przemysław Śleszyński ${ }^{1}{ }^{1}$, Maciej Nowak ${ }^{2}$, Paweł Sudra ${ }^{3}{ }^{\circledR}$, Magdalena Załęczna ${ }^{4}$ and Małgorzata Blaszke ${ }^{2, *}$ \\ 1 Department of Urban and Population Geography, Institute of Geography and Spatial Organization, \\ Polish Academy of Sciences, 00-818 Warsaw, Poland; psleszyn@twarda.pan.pl \\ 2 Department of Real Estate, Faculty of Economics, West Pomeranian University of Technology, \\ 70-310 Szczecin, Poland; Maciej.Nowak@zut.edu.pl \\ 3 Department of Housing and Urban Renewal, Institute of Urban and Regional Development, \\ 03-728 Warsaw, Poland; psudra@irmir.p1 \\ 4 Department of Investments and Real Estate, Faculty of Economics and Sociology, University of Lodz, \\ 90-255 Lodz, Poland; magdalena.zaleczna@uni.lodz.pl \\ * Correspondence: mblaszke@zut.edu.pl
}

check for

updates

Citation: Śleszyński, P.; Nowak, M.; Sudra, P.; Załęczna, M.; Blaszke, M. Economic Consequences of Adopting Local Spatial Development Plans for the Spatial Management System: The Case of Poland. Land 2021, 10, 112. https://doi.org/10.3390/land10020112

Received: 29 December 2020

Accepted: 21 January 2021

Published: 25 January 2021

Publisher's Note: MDPI stays neutral with regard to jurisdictional claims in published maps and institutional affiliations.

Copyright: (c) 2021 by the authors. Licensee MDPI, Basel, Switzerland. This article is an open access article distributed under the terms and conditions of the Creative Commons Attribution (CC BY) license (https:// creativecommons.org/licenses/by/ $4.0 /)$

\begin{abstract}
The spatial management system in Poland struggles with serious costs as a consequence of local planning. The problem is the lack of appropriate value capturing mechanisms and cost compensation for municipalities, along with significant burdens. Private property is subject to special protection, but the public good is less valued. The article attempts to assess the situation in Poland, recalling also the experiences of spatial management systems from other European countries. It combines legal, economic, and geographical perspectives. The specific objectives were demonstration of geographical (interregional and functional) regularities related to the economic (financial) consequences of adopting local plans and identification of financial effects resulting from the implementation of local plans in communes, i.e., in particular, their size, structure of revenues (income), and expenditures, in relations with the budgets of municipalities and the population living in communes. First, the determinants of spatial policy were defined in the context of institutional economics and the real estate market. Then, a unique database of forecasted and realized budgetary revenues and expenditures of 2477 communes in Poland related to spatial development (infrastructure construction, land transformation, purchase, etc.) was analyzed statistically. Additionally, for five selected communes of different functional types, this issue was examined in detail. It has been shown that municipalities do not derive adequate income from spatial development, and improper policy of local self-governments results in heavy burdens, threatening to disturb their financial balance. The formulated conclusions regarding the legal, economic, and spatial mechanisms may contribute to building tools (instruments) for more effective spatial management in various countries.
\end{abstract}

Keywords: local development; local law; budgets of local units; financial consequences of spatial chaos

\section{Introduction: Assumptions and Goals}

The spatial management system and the use of spatial policy tools must always be related to the conditions existing in the real estate market. These institutions are interdependent with each other. The legislator should be able to notice this in every country, appropriately balancing interests of "actors" interested in creating legal solutions in this respect. Much depends on the specific institutional framework, both formal and informal, relating to planning practice. Geographical areas (territories) should be covered by legal acts regulating land destination principles, and the use of the local planning practice should complement their function. If this regulatory role of spatial planning is not fully realized, there is a scope for spatial conflicts to arise [1]. 
Difficulties in building an appropriate institutional framework result from two ways of sharing the good of limited space: public and private ones. On the one hand, there is a need to conduct an active spatial policy on a local scale, which should effectively protect the area's values related to spatial order; on the other hand, real estate market participants, especially owners, would like to benefit from their rights. Against this background, contradictions occur that are sometimes difficult to reconcile [2-4]. Failure to properly fulfill the regulatory role also means a waste of resources present in space. Improper allocation means a lack of optimal use, e.g., irrational land use and suboptimal distribution of various functions based on these resources [5-8]. The consequences of spatial conflicts are wide and cover all spheres of human activity in geographical space.

That is why the role of local spatial development plans (from now on referred to as local plans) is so important. They are key (regulatory) tools of spatial policy, which are, at the local level, most responsible for determining the land use. Local plans significantly affect the value of real estate and the real estate market. The local plans are subject to research as signals that can influence the decisions of interested actors $[9,10]$ and impact of the process of preparing planning framework [11]. The results of some analyses indicate increase of real estate value in consequence of adoption of local plans [12,13]. Among other directions of research, the impact of planning acts on the supply and prices of housing shall be mentioned [14,15]. However, the use of local plans in European countries is different: they have a different scopes and legal effects. In some spatial management systems, it is the impact of plans on the value of a property that determines the frequency of preparation of plans due to the costs of their implementation for public actors.

Less frequently discussed issues include the economic consequences of spatial regulations influencing real estate market participants' behavior. In this context, Poland seems to be an interesting example because of the complicated and inefficient spatial planning system, generating costs estimated at the level of at least EUR 20 billion per year [16]. They also include the impact of spatial chaos on the real estate market.

Against this introductory background and problem formulation, the objectives of the article are

- the demonstration of geographical (interregional and functional) regularities related to the economic (financial) consequences of adopting local spatial development plans, and

- the identification of financial effects resulting from the implementation of local plans in municipalities (communes), i.e., in particular, their size, structure of revenues (income), and expenditures, in relation with the municipal budgets and the population living in communes.

To achieve these goals, the article first defines the conditions of the spatial policy in the context of governance failure and the real estate market, combining these issues with the problems of spatial management systems in Europe, which are discussed in the literature. Against this background, we present Polish experiences concerning the economic consequences of adopting local plans, which make up the essential empirical part of the article. The focus is on the regularities related to the effects of implementation of local plans on the municipal budgets, according to the functional types of communes. In this context it is worth to add a terminological clarification. Gmina is a basic local administrative unit (LAU) in Poland. It corresponds to the former NUTS-5 level, that is, the LAU-2 level, according to the classification of Eurostat. The term "commune" is used commonly for an English synonym of gmina as the smallest territorial division for administrative purposes in Poland. Therefore, it will be used interchangeably in the text with the universal term "municipality".

Against this background, a thesis is formulated that improper regulations, combined with governance failure in the spatial management system, result in a burden on budgets of communes. Estimating the economic effects of local plan arrangements is important both from the viewpoint of rationalizing the local spatial policy and the sustainability of communes' public finances. We associate it with the optimization process, i.e., reaching the 
best spatial management decisions $[17,18]$. The tool used to achieve this goal is the forecast of the economic effects of the adoption of a local spatial development plan (from now on referred to as the forecast), the implementation of which in Poland is an obligatory element of the procedure for developing a draft local spatial development plan. The Polish spatial management system belongs to the systems classified as protecting real estate owners rights in particular. Its detailed analysis is important for several reasons:

- $\quad$ there are clear regulations regarding the compensation of a reduction in the value of real estate by local plans; therefore, it is much easier than in many other countries to determine municipal expenditure related to spatial planning;

- $\quad$ these expenses can therefore be compiled as a whole and compared with the incomes of communes resulting from the adoption of local plans; on this basis, individual types of communes can be distinguished; and

- the results of these comparisons constitute an important point of reference, which will provide several detailed materials for the discussion of the legitimacy of the application of individual Value Capturing instruments and the consequences of an excessively liberal approach to property owners' rights.

The article combines (and unifies) the economic, geographical, and legal perspectives. Developing an approach combining the showed perspectives and enabling the achievement of research objectives with their careful consideration should be a new contribution to the literature dealing with spatial planning and development issues. In the literature on the subject, the issues of economic consequences of spatial planning are considered limited in the dimension relating to all municipalities in a given country. Such an analysis in this publication makes it possible to distinguish groups of communes with different trends in this respect, which also entitles wider conclusions.

In our literature review, we identified the conditions and the problems of the role of local plans and of the economic consequences of spatial planning in European countries. We have highlighted the specificity of the Polish system against this background. Then, we analyzed all communes in Poland in relation to the following issues: forecasted revenues and expenses resulting from adoption of the local plans and realized revenues and expenses relating to the above forecasts. In the Discussion, we applied the conclusions resulting from the research to a wider discussion on the economic consequences of spatial planning.

\section{Research Method and Source Materials}

For the purpose of exploring the diversification of the financial implications of local planning, data from a survey "Spatial planning in the commune" (carried out by the ministry responsible for the "spatial management" public affairs sector and the Central Statistical Office under the Public Statistics Research Program) were used. This survey consists of collecting responses from all communes in Poland (2477 units in 2019) on the following issues:

- forecasted revenues and expenses related to the adoption of local plans, which are specified in the obligatory documents entitled "Financial impact forecast of a local spatial development plan", and

- $\quad$ realized revenues and expenses relating to the above forecasts.

We used the latest available data for 2019, showing the current implementation of local plans' provisions. In terms of revenues (forecast and realized), these were revenues to communal budgets resulting from (1) planning fee, (2) increase in property tax, (3) tax on civil law transactions, and (4) category of "other" costs. In terms of costs, we took expenses of local budgets into account, which are related to (1) construction of communal roads, (2) purchase of land for roads, (3) construction of technical infrastructure, and (4) other costs included in the "other" category.

Responses have been obtained from a different percentage of communes in the country, depending on the thematic group of the questions (forecast, current status, income, and expenses) - it was 49.5-63.0\% of local governments. Out of 2299 communes with local plans, 
$915(39.8 \%)$ answered questions from all four groups, another $309(13.4 \%)$-questions from three groups, and $386(16.8 \%)$ - questions from two groups, and $136(5.9 \%)$ to questions from one group. In 1746 communes $(75.9 \%)$, at least one answer was given. It was possible to collect comprehensive and unique material that allows analyzing and testing the economic effects related to the adoption of local plans on a very detailed spatial scale, and thus to conclude on impacts of spatial planning on the real estate market.

Datasets from the Local Data Bank of the Central Statistical Office for 2017-2019 were used as regards the information on communal budgets. Taking the three-year period into account was aimed at averaging the data in order to avoid local governments' financial indicators' volatility over time. The analyses used the indicator of total communes' income and their self-income ratio. Total revenues of municipalities in Poland include their own revenues, as well as general subsidy (which is a form of redistribution of state revenues, e.g., from taxes) and specific subsidies from the state budget. Own revenues include local taxes (on real estate, means of transport, small business, inheritance and donations, civil law, agricultural, and forestry activities) and revenues from local fees (stamp duty, market fee, maintenance fee, spa fee, etc.).

The division of communes in Poland into types, the so-called functional classification, has been developed specifically for spatial planning monitoring purposes [19]. It distinguishes ten types of communes based on the administrative and functional hierarchy of cities and towns (voivodeship capitals, sub-regional, and local centers), specific locations of communes (suburban zones and transport corridors), and economic functions (tourism, agriculture of various intensity, etc.). To obtain proper generalization, the communes were aggregated to 10 types. Table 1 includes basic information about the distinguished types.

Table 1. Basic information about the analyzed categories of communes.

\begin{tabular}{|c|c|c|c|c|c|}
\hline Type of Gminas (Communes) & $\begin{array}{l}\text { Number of } \\
\text { Entities }\end{array}$ & $\begin{array}{c}\text { Area } \\
\text { (Thous. ha) }\end{array}$ & $\begin{array}{l}\text { Population } \\
\text { (Thous.) }\end{array}$ & $\begin{array}{l}\text { Number of } \\
\text { Local Plans }\end{array}$ & $\begin{array}{l}\text { Coverage } \\
(\%)\end{array}$ \\
\hline A-functional urban areas of voivodeship capitals & 33 & 500 & 9563 & 4529 & 47.5 \\
\hline B-their external zones & 265 & 2759 & 4873 & 12,181 & 44.4 \\
\hline C-functional urban areas of sub-regional centers & 55 & 340 & 4322 & 3402 & 56.5 \\
\hline D—their external zones & 201 & 2147 & 2452 & 5040 & 39.1 \\
\hline E-multifunctional urban centers & 142 & 1027 & 3783 & 4606 & 31.8 \\
\hline $\mathrm{F}$-communes with developed transport functions & 137 & 1996 & 1435 & 2615 & 31.1 \\
\hline $\begin{array}{l}\text { G-communes with other developed } \\
\text { non-agricultural functions (tourism and large-scale } \\
\text { functions, including mining) }\end{array}$ & 222 & 3386 & 1817 & 5695 & 28.6 \\
\hline $\begin{array}{l}\mathrm{H}-\text { communes with intensively developed } \\
\text { agricultural functions }\end{array}$ & 496 & 6297 & 3048 & 4949 & 26.6 \\
\hline $\begin{array}{l}\text { I-communes with moderately developed } \\
\text { agricultural functions }\end{array}$ & 665 & 8653 & 5179 & 9119 & 33.2 \\
\hline $\begin{array}{l}\text { J-extensively developed communes (with forests or } \\
\text { nature protection areas) }\end{array}$ & 261 & 4166 & 1910 & 3490 & 19.4 \\
\hline Total & 2477 & 31,271 & 38,383 & 55,626 & 31.2 \\
\hline
\end{tabular}

\section{Literature Review}

Local land use plans have different scope and consequences in different countries. Therefore, they should be compared with great caution. Despite even similar legal regulations, the planning practice may differ [20-23]. However, common features and consequences can be distinguished. They mainly concern 
- the issues of public capacity to control spatial development and the optimal scope of such control [24,25],

- possible and potential land development limitations included in local plans and the related understanding of the ownership right, and

- changes in real estate value due to local plans, the consequences of compensation, and instruments related to the above issues.

The article focuses primarily on the last two issues. However, their interdependence should be emphasized. The limited ability to control spatial development in a given system entails several negative consequences associated with governance failure [26-30]. It also significantly influences the real possibilities of limitations in land development [31,32] and the relationship between local plans and real estate value. In the latter context, many studies can be distinguished, concerning, among other things, the impact of planning acts on the supply and prices of housing $[14,15,33,34]$ and the impact of protection of urban greenery in the spatial plans on the residential real estate value [35-37]. There are publications that broaden the discussion about the role of local plans in shaping the value of real estate. Nestico et al. [13] draw attention to the link between the process of housing development, and planned environmental and socio-economic conditions. Rebelo [9], considering possible institutional changes, emphasizes the importance of social determinants when considering the economic consequences of spatial planning. Cho et al. [12] show that the impact of spatial planning on the value of real estate also depends on the level of development of civil society in a given area.

In the literature on the subject, various classifications of spatial management systems have been made. By limiting ourselves to European countries' comparisons, one can cite classifications distinguishing regional economy planning, integrated planning, land use planning, and urban planning [38]. This gave rise to further classifications, in which the criteria considered included, among others, linking the development with real opportunities existing in the given area (i.e., access to technical infrastructure), the arbitrariness of local authorities in terms of shaping space, as well as the degree of linking planning processes with legal regulations [39-42]. Applying individual regulations is influenced by planning practice that varies in individual countries, resulting from social, cultural, or economic conditions. From the perspective analyzed in this article, the key seems to be the classification of spatial management systems into systems based on local plans (e.g., Spain, partly Italy, France, and Belgium) and systems based on development planning (Great Britain) [43]. Thus, it can be assumed that both the overall concept of the spatial management system and individual solutions are important. From the perspective of this article, important is the classification made by R. Alterman [31]. It distinguishes groups of countries from the perspective of understanding of the property rights in the spatial management system and the scope of compensation rights. The group with minimum compensation rights includes the United Kingdom and France, and the group with extensive compensation rights includes Germany and Poland. As indicated above, individual countries differ in many respects (legal regulations, planning practice, and degree of integration of development planning with spatial policy).

However, the functions of local development plans can be compared. In the United Kingdom, planning acts define the spatial development strategy, which the public administration interprets when issuing building permits. Thus, British local plans are a combination of Polish "studies of land use conditions and directions" (which will be introduced further on) and local zoning plans. In addition to the basic strategy, they specify land use and the areas whose development is crucial. They also contain guidelines for assessment when issuing building permits [44,45]. In France, local urbanistic plans are acts defining in detail the local development principles. They define the general directions of local policies related to spatial policy and define specific actions (important from an environmental perspective). They also define the detailed conditions for the development of individual areas [46,47]. In Germany, there is a land use plan and a development plan on the local level. The former, which is drawn up for the entire municipality, is a preparatory building plan that defines 
the general use of land. The development plans are directly binding on the property owners in terms of development parameters and land development [45,48]. Thus, the local plans' functions are understood in different ways, and, in the selected countries, the individual plans contain a "strategic" part and a part with direct guidelines. Therefore, the scope of limitations of property owners' rights and the financial (compensation) consequences of adopting plans can be considered in different variants. Moreover, for this reason, solutions of individual countries related to the economic consequences of spatial planning should be of particular interest for the researchers, as well as (irrespective of the above) cases of countries shall be investigated where extensive compensation rights are provided for.

It is worth to introduce a few individual solutions concerning spatial planning's economic consequences in different countries. In some European countries, model solutions relating to the discussed sphere have been developed. First, the concept of Value Capturing can be invoked. According to it, public entities' planning decisions transfer the costs of public infrastructure and social housing to private entities, whose property value has increased [49]. The above solutions are justified, among others, by the reasons related to the need to reimburse costs incurred by public entities, taking over some negative costs by private entities creating them, as well as the need to mitigate the impact of new investments on the environment [50-53]. The effectiveness of this process depends on several variables. From the investors' perspective, the key is the certainty of specific solutions and public authorities' flexibility to adapt to their concepts (in this case, the authorities' flexibility should not be confused with opportunism). In this perspective, there may be greater investor uncertainty in Great Britain than, for example, in Spain. This uncertainty may determine the failure of specific investments [43]. From the perspective of considering the consequences of reducing real estate value, the literature indicates nonfinancial compensation options [54]. One of them may be the TDR principle adopted in the United States and disseminated in Europe (e.g., in Italy), including the "transfer of development rights", i.e., a specific "transfer" of the possibility of a certain development to another area $[55,56]$. One can also cite the concept of spatial concentration of development rights related to TDR (Klaus 2020). In individual European countries, the scope of financial compensation depends on understanding property rights and the degree of possibility of limiting it. For example, in Great Britain, local plans may introduce restrictions without any compensation $[44,55]$. However, in some countries, there are large irregularities, the most famous of which are mismanagement and simple fraud in setting up the so-called land banks [57], i.e., in the land banking system developed in the last half-century and provided for in the planning and investment procedure [58]. It is worth pointing out that these institutions, essentially intended to counteract the fragmentation of agricultural land, were gradually also directed, e.g., in the Netherlands and Germany, towards implementing public goals [59].

It has been indicated above that apart from individual solutions concerning the economic consequences of spatial planning in European countries, it is worth noting the case of a country classified in the literature as providing for extensive compensation rights in the spatial management system. This country is Poland. It should be pointed out that in post-socialist countries undergoing political transformation after 1989, a common problem is a too liberal approach to the role of property owners in the spatial management system. It results, to a significant extent, from a kind of rebound after the period of centrally controlled economy, which included excessive control of the private property (including numerous cases of takeovers by the state). As early as at the beginning of the first decade of the transformation (1990s), there were still voices that the flawed real estate market system inherited from communism, including the disordered ownership structure, will be a serious burden for a smooth transition to a free market system [60], including society's understanding of the rational principles governing the relationship between private property and the common good. As a result, many countries in this bloc are still, after three decades of transformation, diagnosed with problems of uncontrolled development, misunderstanding what the public interest is, and spatial chaos [61-63]. 
The spatial management system of Poland is the subject of numerous critical analyses [64-67]. In the opinion of the vast majority of the representatives of the literature on the subject, it does not fulfill its role by not ensuring sufficient protection of the spatial order, nor by stopping the negative spatial trends (including urban sprawl, uncontrolled development, increasing costs of spatial chaos in the settlement, environmental, or transport dimensions [16]). The key tools of spatial policy exist at the commune (local) level. "Studies of land use conditions and directions" (pol. Studium) are documents of directional and strategic nature which are mandatory in every commune; however, they do not directly bind property owners and investors. They may be described as specific equivalents of the former "structure plans" in Great Britain. On the contrary, local spatial development plans (pol. Plan miejscowy), which are equivalent to zoning plans, constitute local law acts but are not obligatory-the commune authorities may adopt them at their discretion (consequently, most of the country is not covered by these plans-the coverage of the territory of Poland with binding local plans in Poland at the end of 2019, which was only $31.2 \%$ ). Development in areas without adopted local plans is carried out based on administrative proceedings related to the issuance of an individual decision on development conditions [68]. A huge number of decisions issued leads to the aggravation of negative phenomena related to uncontrolled development.

The financial consequences of adopting a local spatial development plan (increasing and decreasing real estate value) have been included in the Act on spatial planning and development from the 27 March 2003. According to Art. 36-37 of the Polish Act, if the local plan restricts the existing possibilities of developing the property in a way that the current development cannot be continued, the commune, by adopting this plan, is obliged to pay the owner of the property compensation equal to the damage suffered. As soon as the property's value decreases and the owner disposes of it within five years of the plan's entry into force or its amendment and has not previously benefited from compensation, he/she has the right to demand compensation equal to the loss value. On the other hand, in a situation where the local plan extends the possibilities of real estate development relating to the previous possibilities and causes an increase in its value, there are no adequate consequences [69]. If the owner of such real estate sells it equivalently within five years from the local plan's effective date, he/she will pay a special fee, the so-called planning rent (a zoning-change fee). Depending on the communal authorities' discretion, it may amount up to $30 \%$ of the increase in the property's value (the rate should be included in the plan). It is a specific value capturing mechanism.

\section{Financial Effects of Local Plans in Poland}

\subsection{Forecasted Revenues}

According to the data obtained from 1757 communes ( $75 \%$ of those having valid local plans), the state shown according to the forecasts prepared in the years 2003-2019 was as follows. The projected revenues resulting from local plans' adoption were shown for PLN 69.4 billion (PLN 1 billion $\approx$ EUR 240 million in 2019). The most important share were the proceeds from "other" category (PLN 26.2 billion) and from the increase in property tax (PLN 24.7 billion), followed by the planning fee (PLN 16.3 billion) (Table 2; Figure 1). It should be emphasized that the vast majority of forecasts do not have a specific time horizon: neither minimum nor maximum.

The highest revenues were forecasted in large urban centers, including voivodeship capitals (type A)-PLN 22.3 billion, and in neighboring communes belonging to Functional Urban Areas of voivodeship cities-PLN 14.7 billion. In cities with poviat (county) capital status and generally sub-regional cities (type $\mathrm{C}$ ), total revenues were expected to amount to PLN 9.1 billion. For the remaining types of communes, a significantly lower sum of incomes was forecasted, including the lowest one in the group of extensively developed communes, which have a high share of forests and protected areas (type J)—PLN 1.5 billion, in intensively agricultural communes (type $\mathrm{H}$ ) - 2.0 billion PLN, and in communes related to the function of communication nodes (type F)—PLN 2.4 billion. 
Table 2. Basic quantitative information on the forecasted and realized incomes and expenditures related to adopting local spatial development plans in 10 types of communes, for the year 2019.

\begin{tabular}{|c|c|c|c|c|c|c|}
\hline \multirow{2}{*}{$\begin{array}{c}\text { Type of } \\
\text { Communes * }\end{array}$} & \multicolumn{2}{|c|}{ Revenues (mln PLN) } & \multicolumn{2}{|c|}{ Expenditures (mln PLN) } & \multicolumn{2}{|c|}{ Balance (mln PLN) } \\
\hline & Forecasted & Realized (Obtained) & Forecasted & Realized (Incurred) & Forecasted & Realized \\
\hline $\mathrm{A}$ & 22,328 & 760 & 44,452 & 3680 & $-22,124$ & -2919 \\
\hline B & 14,737 & 4572 & 21,208 & 6910 & -6470 & -2338 \\
\hline $\mathrm{C}$ & 9079 & 4081 & 13,363 & 4495 & -4285 & -415 \\
\hline $\mathrm{D}$ & 4176 & 1911 & 6096 & 1851 & -1921 & 59 \\
\hline $\mathrm{E}$ & 5495 & 1628 & 8577 & 3437 & -3083 & -1809 \\
\hline $\mathrm{F}$ & 2427 & 290 & 2544 & 824 & -117 & -533 \\
\hline G & 3183 & 1136 & 4236 & 1754 & -1053 & -619 \\
\hline $\mathrm{H}$ & 2030 & 354 & 2772 & 693 & -741 & -339 \\
\hline $\mathrm{I}$ & 4499 & 1028 & 8770 & 2109 & -4271 & -1081 \\
\hline $\mathrm{J}$ & 1470 & 292 & 2343 & 904 & -874 & -612 \\
\hline Total amount & 69,423 & 16,052 & 114,361 & 26,658 & $-44,938$ & $-10,606$ \\
\hline
\end{tabular}

* abbreviations of types of communes explained in Table 1. Source: based on unpublished data of the Ministry of Development and Statistical Office of Poland.

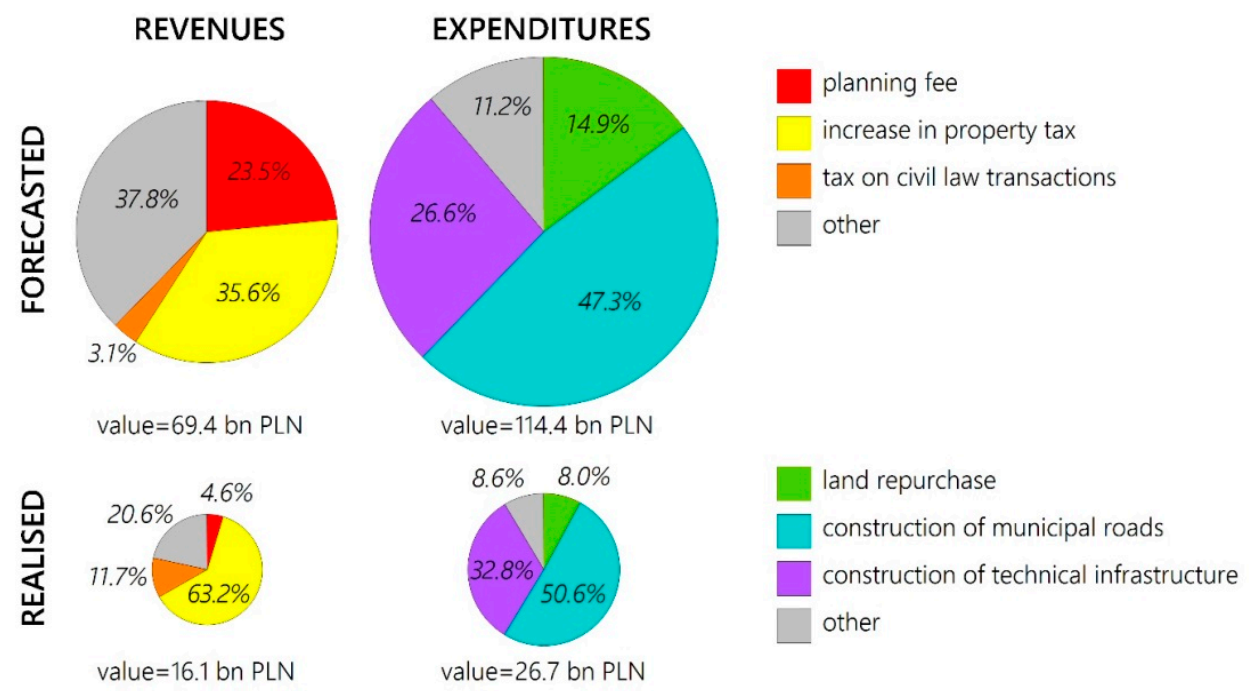

Figure 1. Structure of forecasted and realized revenues and expenditures of communes as a result of local plans enacted, for the year 2019. Source: based on unpublished data of the Ministry of Development and Statistical Office of Poland.

The highest projected revenues were found in Warsaw (PLN 4.9 billion). It was about $7 \%$ of the total for the whole country, which is more or less similar to the population potential of the 1757 communes studied. Due to land prices in the capital, this value seems relatively low. Moreover, high income was expected in Szczecin (PLN 3.9 billion), and over PLN 1 billion in Sosnowiec, Cracow, Gdynia, Rzeszów, Gliwice, and Poznan. The high concentration of quotas in a relatively small number of communes draws attention. Half of the local binding plans' forecasted revenues were concentrated in only $3.6 \%$ of the communes that reported any amounts (64 out of 1757 local government units).

Despite the obvious differentiation of forecast impacts between large urban centers and peripheral communes, such drastic disproportionality may prove inconsistency and different methodological approaches in forecasting. It is possible both to overestimate the expected revenues and to lower them. Another probable cause of the observed dispropor- 
tions is inconsistently conducted, ineffective financial management in some communes. In any case, it can be stated that there is some irrationality in the spatial management.

\subsection{Forecasted Expenditures}

The projected expenditure was shown at the end of 2019 at PLN 114.4 billion, of which over 38\% (PLN 44.5 billion) was allocated to voivodeship cities. Among the anticipated costs, primarily the costs of construction of communal roads were indicated (PLN 54.1 billion) and, second, the costs of other technical infrastructure (PLN 30.4 billion). The purchase of land for the construction of communal roads was forecast at PLN 17.0 billion. Still, this amount is probably underestimated by including these expenses partially under the item "construction of communal roads".

The forecasted expenditure was concentrated in particular in two voivodeships: Mazowieckie (PLN 24.9 billion) and Zachodniopomorskie (PLN 14.1 billion). Suppose we recalculated them relating to the number of people. In that case, it gives an amount per capita of 4.6 thousand PLN in the first voivodeship and as much as PLN 8.3 thousand-in the second (national average-PLN 3.0 thousand). However, these calculations do not consider that no data was obtained for over $35 \%$ of communes.

It is visible that the burden on communes' budgets due to the adoption of local plans may be significant. In fourteen communes, the forecasted amounts exceeded PLN 1 billionthe highest was in Szczecin (PLN 12.3 billion), Warsaw (PLN 10.6 billion), Poznań (PLN 3.8 billion), and Cracow (PLN 2.8 billion), but high also in smaller communes, especially those located within functional urban areas of voivodeship centers, such as Radzymin (PLN 1.5 billion) and Lesznowola near Warsaw (PLN 1.4 billion), Wieliczka near Cracow (PLN 1.0 billion), and Oleśnica near Wrocław (PLN 2 billion).

A high concentration of forecast expenditure amounts was observed in a relatively small number of communes. The first ten communes concentrated as much as $33.6 \%$ of the projected expenditure in the whole of Poland, and in the first 50 communes, it was as much as $53.6 \%$. It again indicates the need for in-depth research to verify the methodology of financial forecasts; the adoption of local plans, including the link with the planning coverage; and the content of documents in terms of land allocation structure. Considering the median of the projected costs in communes (PLN 11.1 million) and multiplying it by about 2000 communes, shown for Poland's whole, the total result obtained from the questionnaires (PLN 114.4 billion) may be up to five times overstated. On the other hand, it cannot be ruled out that a significant number of communes underestimated the cost of the financial consequences of adopting the plans.

\subsection{Realized Revenues}

By the end of 2019, the proceeds realized from adopting local plans amounted to PLN 16.1 billion (for 1832 communes out of 2326 where there was at least one good local plan and provided relevant data). Thus, it was over four times less than the forecasted revenues. The following communes generated the highest incomes: Włocławek (PLN 1502 million), Kobierzyce near Wrocław (PLN 558 million), Piaseczno near Warsaw (PLN 410 million), Lesznowola near Warsaw (PLN 383 million), and Ostrów Wielkopolski (PLN 375 million). The most important item in total was the proceeds from the increase in property tax (PLN 10.1 billion, i.e., $62.1 \%)$.

The realization of revenues showed a greater variation by region. The largest revenues were recorded in the following voivodeships: Mazowieckie (PLN 2.2 billion), Wielkopolskie (PLN 2.1 billion), Kujawsko-Pomorskie (PLN 1.9 billion), Dolnośląskie, and Śląskie (PLN 1.8 billion). This occurred because of the exceptionally high income of only a few local governments in the region. In the voivodeships, Mazowieckie, this applies in particular to Piaseczno and Lesznowola (suburban area of Warsaw), Wielkopolskie-Ostrów Wielkopolski, Kujawsko-Pomorskie-Włocławek, and in Dolnoślaskie-Kobierzyce (suburban area of Wrocław). The units with the highest incomes from local plans are both medium-sized, poviat cities (e.g., Włocławek - the former capital of the voivodeship), and rural communes 
within reach of large agglomerations, where a policy of intensive management of previously agricultural land for housing, industry or services (Kobierzyce, Lesznowola).

Although the highest amount of income was forecasted in voivodship cities, the implementation of local plans in communes belonging to their functional areas and subregional cities (poviat or with more than 50,000 inhabitants) brought income 5-6 times higher. In total, these two categories of communes (type B and type C) concentrated $36 \%$ of the obtained income. The lowest incomes were generated (as for forecasts) in extensively developed communes, e.g., forestry type of communes and in the ones with the leading functions of intensive agriculture and transport junctions. On the other hand, the amounts obtained in communes with a moderately agricultural function (type I) were greater than those of the three previously mentioned types (F, H, and J). Still, it must also be said that there is the highest number of moderately agricultural communes in Poland ( $30 \%$ of the total). A similar total level of income was obtained in tourist communes (type I), half higher in small towns located outside the functional areas (type E), and twice as high in external FUA (Functional Urban Area) communes of sub-regional cities (type D).

Among the realized incomes, attention is drawn to a small, even in many cases trace, amount resulting from the planning rent. A detailed analysis of the obtained statistical data shows that, especially for cities with poviat rights status, the provisions enabling the collection of planning fees are practically not applicable. It is a complex problem, partly related to the fact that communes set a zero rate of this fee (with a maximum allowable amount of $30 \%$ ) and various case laws. As a result, the amounts obtained from the planning rent and the total receipts in individual communes vary greatly.

\subsection{Realized Expenditures}

The total expenditure under the existing local plans by the end of 2019 amounted to PLN 26.7 billion, and thus they accounted for $23.3 \%$ of the forecasted expenditure. The outlays were distributed in the following proportions (Figure 1): construction of communal roads-PLN 13.5 billion (50.6\%), construction of technical infrastructure-PLN 8.8 billion $(32.8 \%)$, purchase of land for road construction communes-PLN 2.1 billion $(8.0 \%)$, and other expenses-PLN 2.3 billion (8.6\%).

The largest expenditure was spent on investments in communes belonging to the functional areas of voivodeship centers (PLN 6.9 billion), then in sub-regional cities (PLN 4.5 billion), then in voivodeship cities (PLN 3.7 billion) and other communes (PLN 3.4 billion), and at last, which may be somewhat surprising, in intensively agricultural communes (PLN 0.7 billion), which are particularly numerous in western and northern Poland. The analysis of the structure of expenditures by administrative categories of communes shows that in rural communes the highest costs are related to the construction of technical infrastructure (apart from roads) - they accounted for $47.2 \%$ of the total expenditures in these units. Nevertheless, the total costs of building communal roads and purchasing land for roads were almost the same amount. In urban communes, communal roads' construction was the most absorbed in the expenditure structure $-47.7 \%$ of the total. Its share is even more pronounced in cities with poviat status, where it amounted to $60.9 \%$. Land purchase costs for communal roads were relatively the highest as a category of expenditure in poviat cities $(12.6 \%)$.

The realized costs related to the enactment of local plans differed significantly in individual regions. In the light of the data obtained, the highest costs were incurred in the following voivodeships: Małopolskie (PLN 3.8 billion), Mazowieckie (PLN 3.6 billion), and Pomorskie (PLN 3.1 billion). Expenses exceeding PLN 2 billion were recorded in three more voivodships. The lowest amounts were recorded in Lubuskie (PLN 0.39 billion), then in Podkarpackie (PLN 0.46 billion) and Świętokrzyskie (PLN 0.61 billion). Among all the communes that replied to the budgetary costs incurred, the largest expenditure was made in Gdańsk (PLN 910 million), Jelenia Góra (PLN 857 million), Cracow (PLN 642 million), Piaseczno (PLN 495 million), Tarnów (PLN 491 million), and Białystok (PLN 471 million). The costs incurred in some communes influenced significantly the total 
balance of expenditures for a given region (e.g., Jelenia Góra in Dolnośląskie voivodship$32 \%$ ). In the whole country's scale, the first ten communes generated over $19 \%$ of all expenses. It means a very high concentration, which hinders the unequivocal interpretation of the results and causes that conclusions regarding the situation on a national scale should be cautious.

\subsection{Forecasted vs. Realized Revenues and Expenditures}

The balance of economic effects of adopting local plans is negative, both when we consider the forecasted revenues relating to the forecasted expenditure and the realized results, which can also be observed when converting the amounts to the number of inhabitants of communes (Figure 2). The comparison of income (receipts) and expenses (costs) shows several important regularities. First, neither the expected nor the realized income so far outweighs the expenses. On a national scale, revenues constitute approximately $60 \%$ of the reported costs.
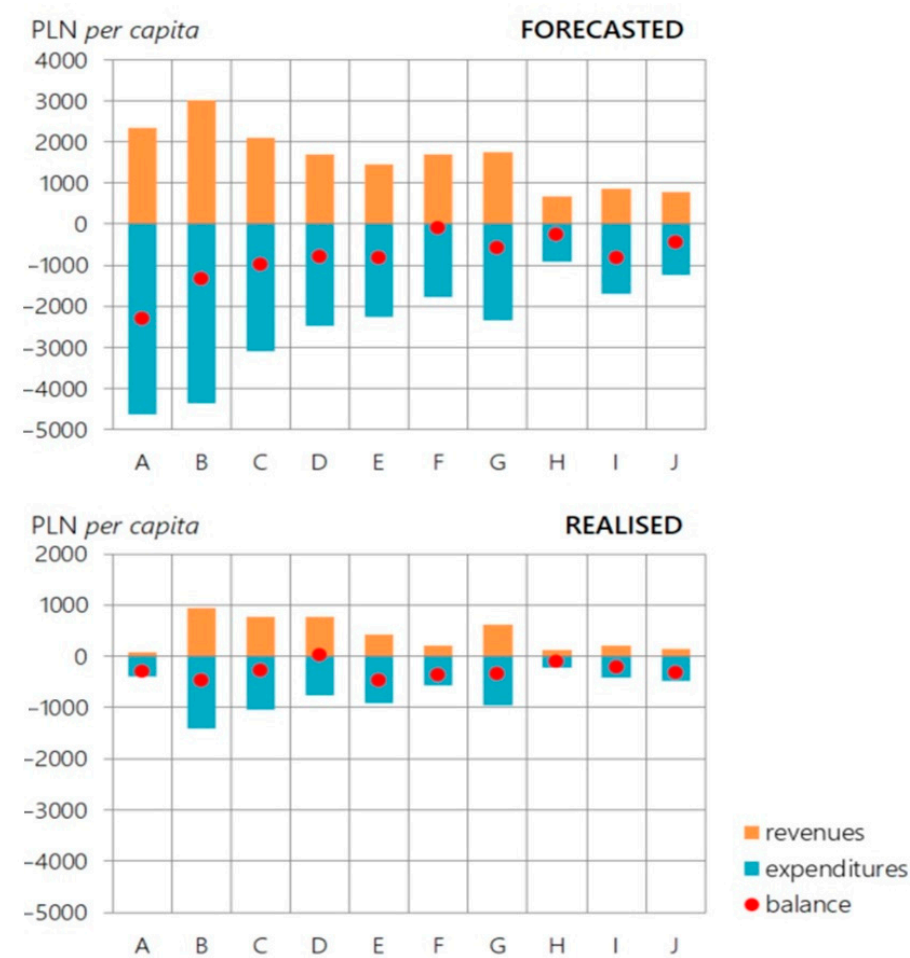

Figure 2. Structure of forecasted and realized revenues and expenditures of communes per capita by types of communes as a result of local plans enacted, for the year 2019. Source: based on unpublished data of the Ministry of Development and Statistical Office of Poland.

The most favorable balance was recorded for the realized income relating to the expenditure by the end of the year in the type $\mathrm{D}$ of communes, i.e., in the external zones of functional areas of sub-regional cities. It was slightly positive there, amounting to PLN 59 million. In the remaining categories of communes there are lower balances for financial turnover. In absolute numbers, the most negative balance concerns the ratio of projected revenues to costs in voivodeship cities (PLN -22.1 billion, thus it was assumed that $50 \%$ of revenues would offset expenditure). Simultaneously, the percentage ratio of revenues to costs was also the least favorable in voivodeship cities, but only in terms of their implementation (only $20 \%$ of revenues offset expenditure). It means that in larger urban centers, the implementation of the economic effects of adopting local plans takes longer. On the other hand, this balance percentage was also very low in the most intensively developed communes, including forest communes (type J), where the income balanced the expenditure by $32 \%$. 
On the country scale, there is almost the same rate of obtaining (realizing) revenues to those forecasted (23.1\%) compared to incurred and forecasted expenses $(23.3 \%)$. It can be concluded that both obtaining funds and incurring expenses resulting from adopting local plans are considerably stretched in time.

The most balanced financial situation related to the implementation of the provisions of local plans was found (apart from the already mentioned functional zones of sub-regional cities, where the balance was minimally positive) in the sub-regional cities themselves, i.e., mainly poviat cities. The negative balance there accounted for $9 \%$ of all expenditure, while in voivodship cities the amount of negative balance accounted for almost $80 \%$ of realized expenses, in smaller towns (type E) it was $53 \%$, and in the most intensively developed communes (type J) $-68 \%$ of the costs incurred.

The maps show the spatial mosaic nature of the anticipated and realized balances of incomes to expenditures per capita throughout Poland. However, the forecasted balances show clear regional differentiation (Figure 3). More favorable balances of forecasts are observed in the Western and North Territories, including Lower Silesia and northern Poland (Pomerania, Masuria, Warmia) than in the south-eastern part of the country (Lesser Poland, Subcarpathian region), characterized by a greater fragmentation of the agrarian structure and land properties, but also by significant coverage with local plans (the case of the Lublin region). Despite this, many communes from the Lublin region did not provide any data (they did not provide the completed forms during the survey). The balances for implementing local plans (Figure 4) show spatially full mosaic character, where communes with a negative balance dominate throughout the country, but communes with a positive balance are also scattered throughout Poland. The ratio of the expected balances to the communes' incomes (Figure 5) again shows a more favorable situation in the northern, western, and south-western parts of the country than in central, eastern, and north-eastern Poland.

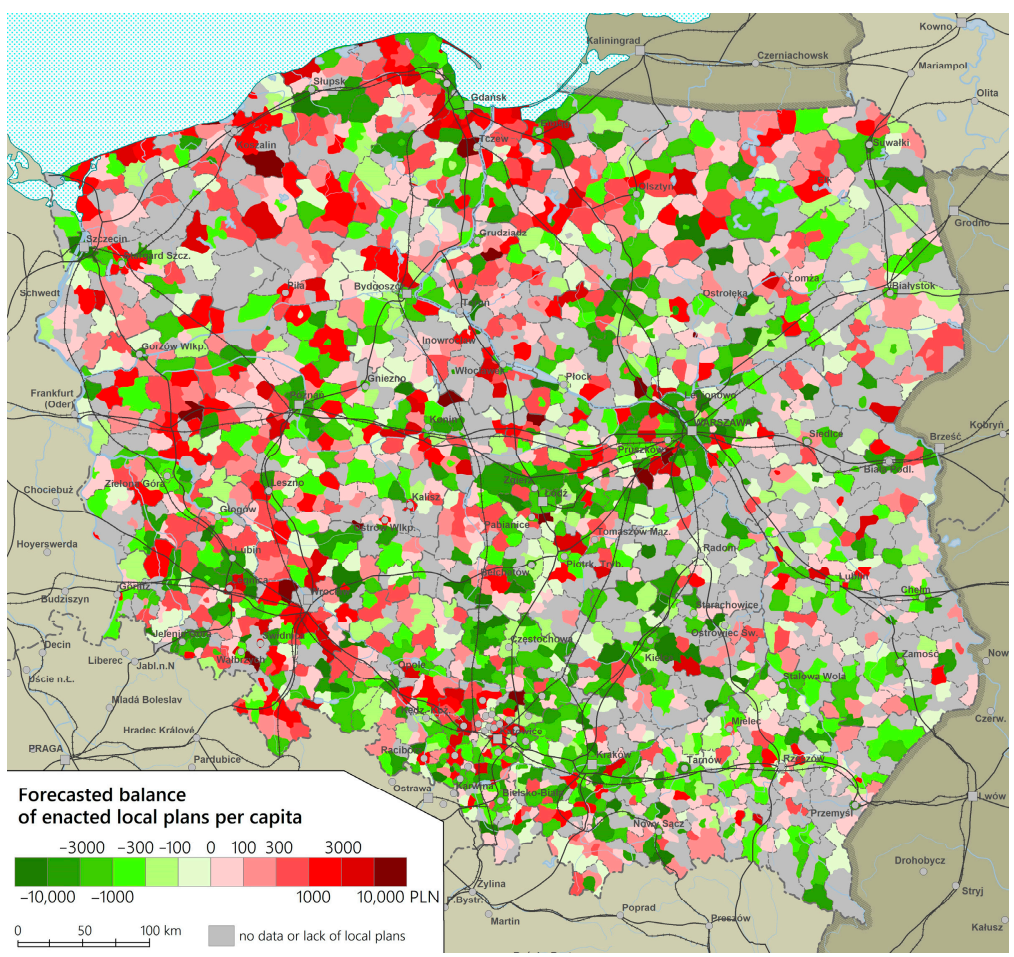

Figure 3. Forecast balance of revenues and expenditures per capita by communes, for the year 2019. Source: based on unpublished data of the Ministry of Development and Statistical Office of Poland. 


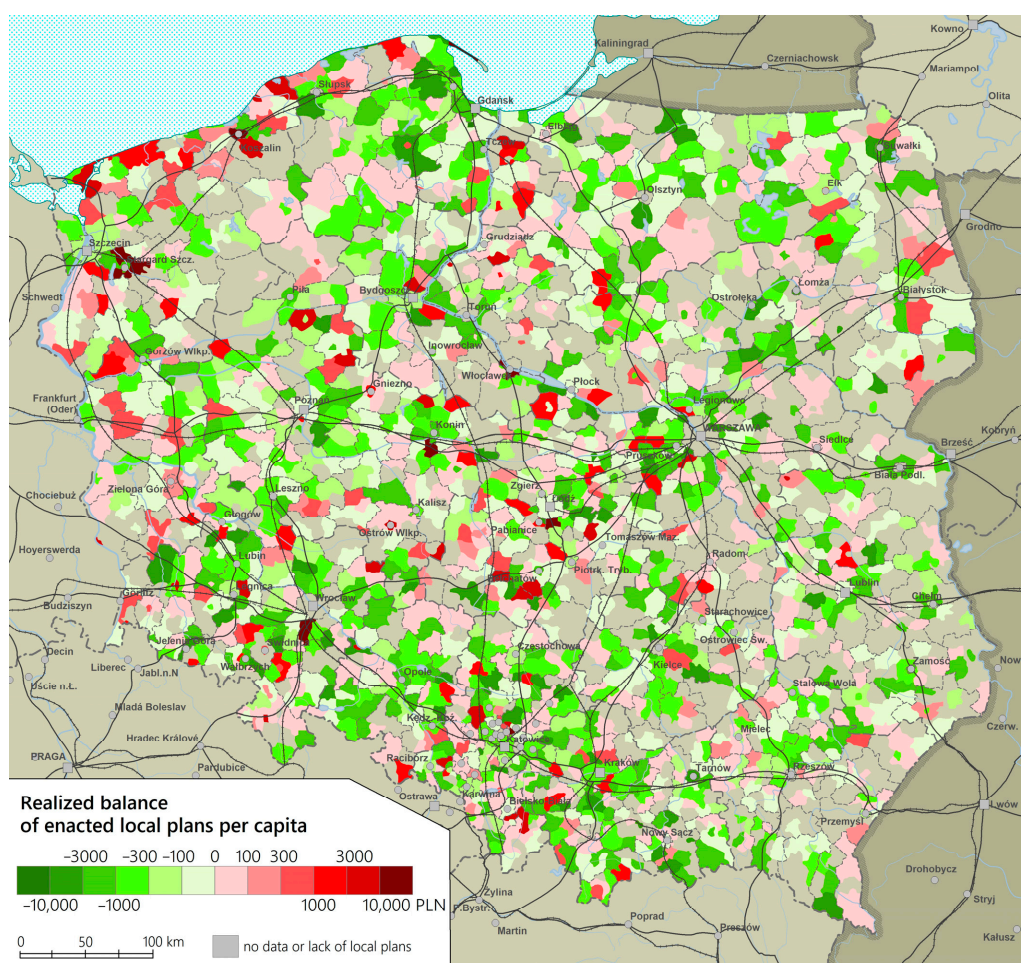

Figure 4. Realized balance of revenues and expenditures per capita by communes, for the year 2019. Source: based on unpublished data of the Ministry of Development and Statistical Office of Poland.

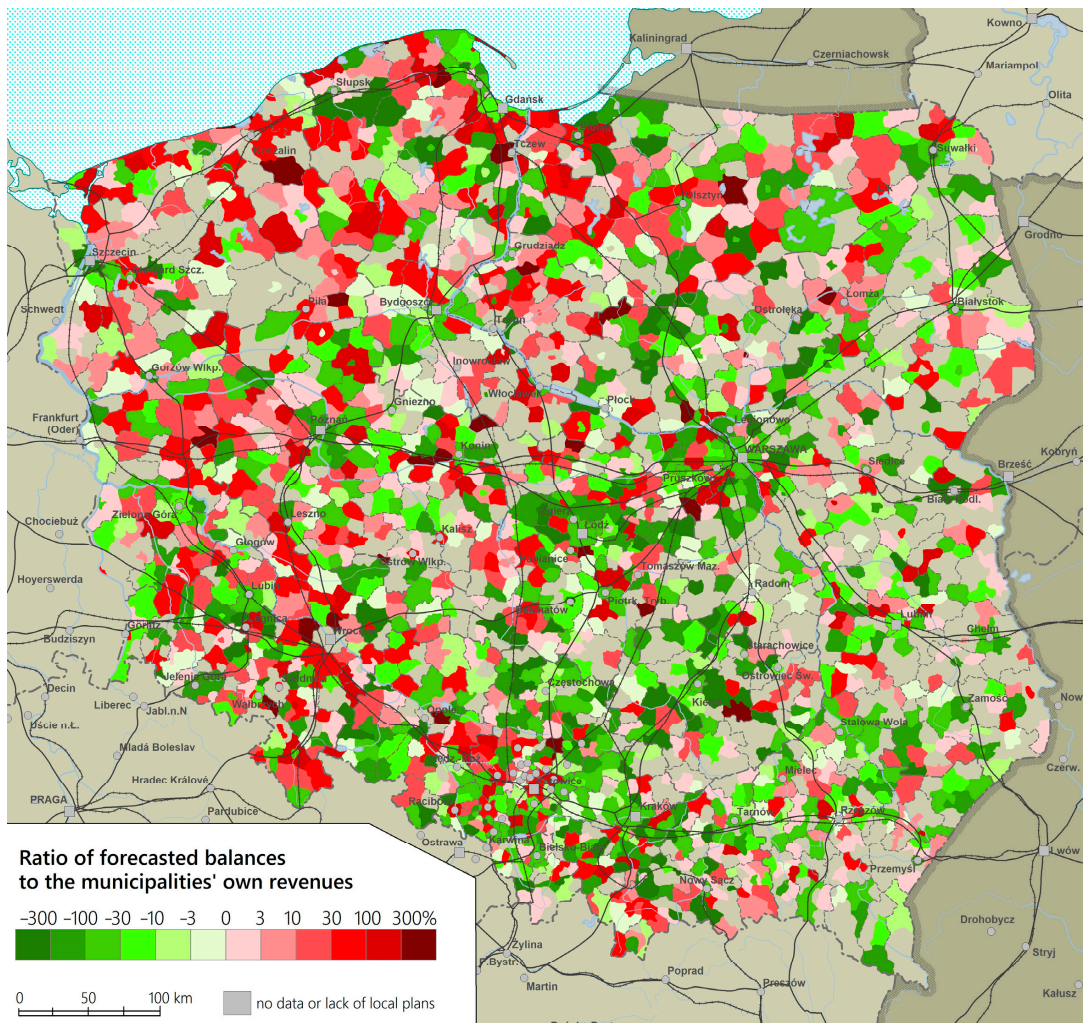

Figure 5. The ratio of forecasted balances to the communes' own revenues, for the year 2019. Source: based on unpublished data of the Ministry of Development and Statistical Office of Poland. 


\subsection{Examples of Municipalities with Unsustainable Financial Management}

The analysis presented in the previous subsections would not be complete if it was not illustrated with examples from specific municipalities. Such a comparison is contained in Table 2, in which information about five municipalities located in different types of municipalities and regions of Poland is collected. They were selected from among $126 \mathrm{com}-$ munes in Poland, for which, at the same time, there were full financial data available (on the forecasted and realized revenues and expenditures), and the area of these communes is nearly completely covered by the binding local plan (more than $95 \%$ of the municipality area). In all of these communes, there were high values of areas for which land use was changed from agricultural to non-agricultural.

All the analyzed municipalities were rather moderately prosperous, as for Polish conditions (municipalities' budgets in the range of 922-1021 EUR per capita, average in Poland-1208 EUR, median 1045 EUR in 2019), including the share of own income (mainly from local taxes and fees) which fluctuated between $31 \%$ and $51 \%$. All the municipalities had a negative balance of projected revenues and expenditures due to the adoption of local plans (the highest number in the Michałowice in Cracow Metropolitan Area-106 million EUR) (Table 3). In three of them, revenues were projected mainly from fees and taxes (92-100\%), while in the remaining ones the sale of building plots was most likely to be the source of profits. Interestingly, the latter mechanism did not apply to places where the land was most expensive, i.e., Michałowice and the Udanin (commune located by the A4 motorway). One can be almost certain that the tool in the form of "land bank" was not used in those communes. While in Michałowice there may have been a problem with the land ownership structure (most or all of the real estate being in private hands for a long time), the A4 motorway route has been known for a long time and it seems "puzzling" that the commune did not buy land along the motorway when plans to modernize the A4 route in 2002-2006 were known (in the commune there are two exits from the motorway: "Udanin" and "Jarosław").

As far as expenditures are concerned, according to the forecasts, they are to be spent mainly on the construction of infrastructure (together with the purchase of land). The amounts for these purposes account for $83-100 \%$ of the expected expenditures in the five municipalities.

In total, all the municipalities are forecast to have a negative balance of forecasted revenues and expenditures, with the largest number of them in the municipality of Michałowice near Cracow ( -91 million EUR). Interestingly, this commune has a positive balance. This is, however, quite a peculiarity, as the commune invests little compared to the needs resulting from the rapid population growth due to suburbanization processes (in the years 2003-2019, the balance of recorded inflows and outflows was positive and amounted to 2.7 thousand people, i.e., $37 \%$ of the population in 2003). It is also worth noting that the commune has an exceptionally unbalanced budget: the planned expenses are as much as 19 times more than its own annual income (1902\%). In the remaining communes this indicator is also high, ranging from 75\% (Kiernozia) to 370\% (Janów Lubelski).

The examples given show quite clearly how serious the problem of the lack of mechanisms is to ensure the financing of investments related to spatial planning in communes. It concerns both the situation in which the commune is an area of new population inflow (Chełm, Michałowice) and a typical depopulation commune (Kiernozia, Udanin). It is particularly unfavorable that despite the latter premise, related to the decrease in population, the communes do not look for savings in better spatial organization and concentration of buildings (in order to, for example, achieve better consistency ("fit") for services), but allow for a strong supply of new investment areas (in the suburban and depopulated communes of Michałowice and Kiernozia it was about 1.5 thousand sq. m of land per capita). 
Table 3. Data on the forecasted and realized revenues and expenditures in the 5 selected communes in Poland. As of 31 December 2019.

\begin{tabular}{|c|c|c|c|c|c|}
\hline Name & Chełm & Janów Lubelski & Kiernozia & Michałowice & Udanin \\
\hline Locality and character & $\begin{array}{l}\text { the suburban commune } \\
\text { around the middle } \\
\text { town, not far from the } \\
\text { border with Ukraine }\end{array}$ & $\begin{array}{l}\text { touristic } \\
\text { commune in } \\
\text { eastern Poland }\end{array}$ & $\begin{array}{l}\text { peripheral agricultural } \\
\text { commune in central } \\
\text { Poland about } 100 \mathrm{~km} \\
\text { north of Łódź }\end{array}$ & $\begin{array}{c}\text { suburban } \\
\text { commune in the } \\
\text { Cracow } \\
\text { Metropolitan Area }\end{array}$ & $\begin{array}{l}\text { commune on the } \\
\text { A4 motorway route } \\
\text { (between Wrocław } \\
\text { and Legnica) }\end{array}$ \\
\hline Population (thous.) & 15.0 & 15.9 & 3.4 & 10.8 & 5.1 \\
\hline $\begin{array}{l}\text { Registered migration } \\
\text { balance (number, } \\
\text { 2000-2019) }\end{array}$ & 2099 & -695 & -131 & 2705 & -322 \\
\hline Area (sq. km) & 221.8 & 178.7 & 76.2 & 51.1 & 110.9 \\
\hline $\begin{array}{l}\text { Number of local plans } \\
\text { including change of land }\end{array}$ & 27 & 11 & 3 & 6 & 70 \\
\hline $\begin{array}{l}\text { use from agricultural to } \\
\text { non-agricultural use (ha) }\end{array}$ & 897 & 728 & 479 & 1714 & 385 \\
\hline sq. m per capita (2019) & 597 & 459 & 1423 & 1593 & 757 \\
\hline $\begin{array}{l}\text { Revenues of municipal } \\
\text { budgets (mln euro) }\end{array}$ & 13.8 & 14.6 & 3.4 & 10.8 & 5.0 \\
\hline per capita & 922 & 923 & 1021 & 1007 & 976 \\
\hline own revenues (\%) & 34.4 & 40.2 & 31.3 & 51.2 & 41.1 \\
\hline $\begin{array}{l}\text { Forecasted revenues } \\
\text { (mln euro) }\end{array}$ & 1.5 & 19.8 & 0.4 & 14.6 & 2.6 \\
\hline $\begin{array}{l}\text { including tax type } \\
\text { revenues }(\%)\end{array}$ & 45.0 & 52.0 & 92.0 & 100 & 98.0 \\
\hline $\begin{array}{l}\text { Forecasted expenditures } \\
\qquad(\mathrm{mln} \text { euro })\end{array}$ & 4.7 & 21.8 & 0.8 & 105.6 & 5.7 \\
\hline $\begin{array}{l}\text { including construction of } \\
\text { infrastructure }(\%)\end{array}$ & 90.2 & 83.6 & 90.9 & 100.0 & 93.5 \\
\hline $\begin{array}{l}\text { Realized revenues } \\
\text { (mln euro) }\end{array}$ & 1.6 & 1.9 & 0.01 & 8.9 & 0.01 \\
\hline $\begin{array}{l}\text { including tax type } \\
\text { revenues }(\%)\end{array}$ & 99.8 & 10.2 & 0.0 & 100.0 & 100.0 \\
\hline $\begin{array}{l}\text { Realized expenditures } \\
\text { (mln euro) }\end{array}$ & 5.0 & 7.2 & 0.5 & 7.5 & 3.2 \\
\hline $\begin{array}{c}\text { Balance of forecasted } \\
\text { revenues and } \\
\text { expenditures (mln euro) }\end{array}$ & -3.2 & -2.0 & -0.4 & -91.0 & -3.2 \\
\hline $\begin{array}{c}\text { Balance of realized } \\
\text { revenues and } \\
\text { expenditures (mln euro) }\end{array}$ & -3.4 & -5.3 & -0.5 & 1.3 & -3.2 \\
\hline $\begin{array}{l}\text { Realized revenues } \\
\text { (\% forecasted })\end{array}$ & 110.2 & 9.8 & 1.0 & 60.9 & 0.01 \\
\hline $\begin{array}{l}\text { Realized expenditures } \\
\text { (\% forecasted })\end{array}$ & 106.4 & 33.2 & 66.0 & 7.1 & 55.9 \\
\hline $\begin{array}{l}\text { Balance of revenues and } \\
\text { expenditures per } \\
\text { capita (euro) }\end{array}$ & -223 & -334 & -162 & 125 & -628 \\
\hline $\begin{array}{c}\text { Forecasted expenditures } \\
\text { as a share of own } \\
\text { revenues }(\%)\end{array}$ & 98 & 370 & 77 & 1902 & 280 \\
\hline
\end{tabular}

Source: based on unpublished data of the Ministry of Development and the Central Statistical Office of Poland.

\section{Discussion}

The presented research covers the whole country. Until now, the literature was dominated by research based on case studies, often related to individual investments. It did not ensure good comparability of the results. It is worth pointing out that our research is representative of a relatively large European country. 
The basic empirical information resulting from the conducted research is the generally negative financial balance of spatial economics at the local level. It results from not using the instruments provided for in the law, including, in particular, obtaining very low fees based on the increase in the value of the real estate (planning rent mechanism). On the other hand, the costs associated with land use changes are high (land purchase, construction of roads, and other infrastructure costs). The balance of income and expenditure in Poland remains negative. It is different from other countries, which generally acquire a financial surplus due to land conversion [59].

In the context of the second aim, it should be concluded, that the research also revealed a very much mosaic (diverse) pattern of communes' regional structure in terms of balances resulting from spatial management. This lack of regularity may prove that the planning law is very "loose". Some communes in their "width" and "freedom" can rationally and profitably conduct spatial and land management, while others are characterized by a negative balance. As shown on the maps, these are often neighboring communes. Meanwhile, the situation is slightly better in the west of the country and worse in the eastern part. It can be hypothesized that this may result from the greater dispersion of settlement in the country's eastern and central parts [70]. On the other hand, the neighboring with each other of the communes with diametrically different financial results cannot be easily explained. However, it seems that the explanation may be cautiously related to the nature of the local economy and local development, based on the strong influence of local communities and elites.

It is worth noting that the research identified groups of communes with the highest incomes obtained based on the indicated types of incomes (these are communes belonging to the functional areas of voivodeship capital cities and sub-regional cities) and communes where the incomes balance the expenses related to local spatial development plans (mainly communes from the external zones of functional areas of sub-regional cities). This research direction will be continued. As indicated above, most income is related to the increase in property value caused by the local zoning plans.

As far as the second objective of the article is concerned, it is important to note the very wide range of expected financial results. Quite often they exceed the annual budgets of municipalities, and there are situations where this ratio exceeds $300 \%$. Thus, it can be a source of big profits, but also a danger because of the problems related to the lack of funds for investments. In this case, the example of large agglomerations shows how diametrically different it is:

- Warsaw, Łódź, Poznań, Cracow agglomeration: the balance is generally negative, often in relation to the budgets of municipalities over $30 \%$ and per capita minus 300 PLN and more;

- Szczecin and Wrocław agglomeration: a positive balance, often in relation to the budgets of communes over 30\% and per capita plus 300 PLN and more.

This confirms those research results which indicate financial instability of self-governments as a serious barrier of development, especially in post-communist countries [71-74].

Despite the diagnosed serious problems in this respect in the Polish spatial management system (which is also presented below in the context of governance failure), the research results lead to the conclusion that these problems can be reduced. Therefore, it is possible to analyze further regularities against this background, particularly the premises for differentiating communes in this respect.

Despite the rich conceptual, theoretical, and implementation achievements in public control and management support in real estate markets (in the broadly understood spatial management system), there is still a wide field for new solutions that help optimize investment and location processes changes in land allocation. Identifying further regularities in this regard seems to be essential for the whole concept of value capturing.

Based on the research, it is also possible to clarify the issue of public governance failure in the spatial economy system. Other areas of it have been identified, which may also be noticeable in other countries. High expenses, which are a consequence of adopting local 
plans in large part of communes, are a serious factor deterring communes from an active spatial policy. These expenses are usually a consequence of the actions of real estate market participants. It can be indicated that the government failure is noticeable in various cases, including the planning and investment procedure in the land banking system [58]. Apart from the accusations of mismanagement, there were spatial conflicts concerning the very role of land banks (e.g., in the Netherlands farmers objected to giving land banks new functions). Therefore, the doubts concerned the form of use and exploitation of public resources (which inherently fits with the dilemmas concerning the concept of value capturing itself). In Poland, serious allegations of mismanagement and fraud appeared, especially in the re-privatization of land in the City of Warsaw [75]. On the other hand, when discussing Poland's local plans' economic consequences, such allegations (on such a scale) were not often expressed.

The creation of binding planning documents may be fraught with the "credible commitment dilemma" [76]. The local community members may not perceive the plans as a solution that is beneficial to them and may not support their implementation. Likewise, local politicians may not be convinced of the political and economic benefits of creating and applying planning documents. Therefore, they will not be interested in creating and implementing them. It is largely related to the understanding of property rights (which varies between countries).

In Poland, this understanding is closer to that of the United States, which more broadly emphasizes the need for compensation for planning restrictions in development [77] and the approach from the Netherlands, emphasizing the rights of the landowner to its increased value because of the provisions of spatial plan [78]. Ultimately, however, it leads to budget problems of public authorities [54], of which the presented situation in Poland is the best example. Non-financial compensation is implemented to a negligible extent and is limited only to selected procedures related to urban regeneration. It is a bad sign for the development of governance in this respect [79]. The solutions from the concept of governance (management through networks, negotiations) not applied in this case allow, together with non-financial compensation (assuming problems related to their application, known for example, from the United States), to limit expenses in this respect. The above confirms that it is necessary to develop an optimal planning style in many European countries [61].

Problems with balancing income and expenditure (and problems with the vast predominance of expenditure) also result from an incorrectly constructed planning rent (fees on the increase in the value of the real estate, i.e., a solution that would implement the Value Capturing concept in Polish conditions). Its optionality, low amount, and the possibility of differentiating its rate are an expression of not only incorrect legislation. As indicated in the literature [48], outside the legal framework, the planning practice determines the implementation of goals which are specific from the spatial management system's perspective. It may come down to informal solutions.

In the case at hand, social pressure led to disseminating informal solutions unfavorable from the spatial management system's perspective: the depreciation of this fee's rates by the communal authorities themselves. It is an interesting example of the public authorities limiting the effects which are positive for them. It should also be added that the possibility of extreme differentiation of rates by public authorities may give rise to allegations of corruption. Such allegations and doubts are noticed (as indicated above) in Western countries. This problem concerns various spheres. Decisions concerning both the spatial development system and the real estate market (i.e., with an impact on real estate value) are discretionary. Discretion in this area as such cannot be eliminated: it would, for example, block the development of planning flexibility.

It is worth paying attention to one more manifestation of public governance failure in the spatial management system identified in the research. It is a severe differentiation of projected and realized expenditure and revenues. From the spatial management system perspective, this significantly hampers rational, planned activities (and this is the standard when implementing the value capturing idea in a significant part of countries). On the one hand, the discrepancies result partly from defective legal bases and, on the other 
hand, also from the practice of public authorities. From the perspective of communal authorities, sometimes the amounts of income and expenditure in forecasts are justified more by political and pragmatic reasons.

The described phenomenon exacerbates the uncertainty indicated in the literature which is related to European spatial management systems in implementing investments related to the Value Capturing instruments [43]. If we add to this the poor flexibility in terms of changes in planning arrangements (and a much greater risk of opportunistic actions), the more understandable are the problems of the Polish spatial management system and the failure of even sector-based urban agreements. It should be emphasized that the overall formal and procedural uncertainty in the Polish spatial development system deepens the speculative actions of investors and a kind of confusion among local authorities.

As indicated in the literature review, local plans in different countries have different formulas and functions. Individual instruments for the economic consequences of spatial planning are also adapted to these plans in different ways. The presented results lead to the reflection that the definition of extensive compensation consequences in the system, combined with the lack of developed individual instruments for the economic consequences of planning, contributes to a gross reduction of control by public authorities of the spatial development (identified in the literature as a key function of plans). Such control-with different legal solutions-is possible to a greater extent, even when local plans are not legal acts (as in the UK). The example of the French system (considering the compensatory consequences of spatial planning to a negligible extent) also leads to the conclusion that the liberal understanding of property owner's rights developed in post-socialist countries (also in Poland) can be repaired even when applying the regulations of the European Convention on Human Rights. This Convention, despite numerous discussions on it, does not only require such an understanding of property rights as in the Polish spatial planning system [31].

\section{Summary}

In the study, we presented empirical evidence to support the thesis that spatial planning and spatial development relating to Poland's real estate market have serious drawbacks, leading to mismanagement and losses. The lack of certainty in the real estate function will be maintained, and the non-transparency of decisions made by local authorities affects the overall market. We compared it to the situation in other countries, concluding that Poland, compared to other countries, is characterized by a deeper degree of public governance failure. The lack of certainty and consistency in legislative solutions, and questionable planning practice, together lead to the domination of expenditures over incomes constituting the economic consequences of adopting plans and to the creation of a large mosaic of communes' regional structure in terms of balances resulting from spatial management. There is no wider use of tools related to the concept of governance in this respect, especially in-depth negotiations before planning decisions. There is also a lack of an objectively indicated scope of changes in the local plan that the public authority may conduct on the occasion of such potential negotiations (and such scopes are, e.g., distinguished in the systems of other countries).

Therefore, the lack of a wider implementation of local plans with poor planning practice perpetuates the negative phenomena (spatial chaos). The compensation claims provided for in the Polish system make it difficult to repair it more broadly. Interestingly, in the context of the concept of Value Capturing, even communal authorities deepen these trends, often not taking advantage of the (limited) possibilities of determining and collecting planning rent. There is also definitely a lack of other value capturing solutions, such as the transfer of the right to build (although it must be noted that even sectoral substitutes for value capturing solutions have not been adopted, an example of which is the urban agreement in the urban regeneration process-provided for in the regulations but not applied). Value capture instruments, which can be used by municipalities when the value of real estate increases due to the constructions of infrastructure from public funds, are also not often used in practice. 
The conducted analyses indicate several important regularities related to financial effects on the binding local spatial development plans in Poland. Inflows and expenses related to the effects of adopting local plans constitute a high percentage of total revenues and expenses of communes' budgets. A relatively permanent phenomenon is the generally negative result of the effects of adopting local plans (a positive balance occurred only in two out of sixteen voivodeships).

The very heterogeneous financial policy of communes is noteworthy, both in terms of spending funds and obtaining income to implement local plans. It also results from a large diversification of communes' activity in the field of spatial planning-relating to the number, area of coverage, and functions of the adopted plans (dominant use of areas, exclusions from buildings, etc.). The functioning system's serious problem is the occasional occurrence of typical income mechanisms provided for in the Act on Spatial Planning and Development (2003), especially related to the planning fee (rent).

As a result of adopting local plans, there is a strong stratification of local governments' income and cost situation. The observed strong concentration of high revenues and expenses in a small part of communes, both forecasted and realized, implies considerable heterogeneity and generally diverse policies of communes in the field of spatial planning. The observed lack of significant regularities — statistical, functional, and spatial—makes us critically evaluate the local spatial policies, which often brings benefits to some local governments in similar socioeconomic realities and geographical locations, and to others it brings (in most cases) losses.

As the projected burden on local government budgets related to the implementation of local plans (due to expenditure on infrastructure, public roads, land purchases, compensation for owners) often does not balance the revenues (from taxes and local fees and real estate trade), communes often suspend works on spatial development plans. It leads to the development of uncontrolled urbanization based on administrative decisions on building conditions, resulting in spatial chaos and has a limiting effect on local development, with serious financial consequences. They are related particularly to the purchase of land, infrastructure construction, and its maintenance in the future. These "extra" costs, increased due to dispersed, chaotic development, are estimated at EUR 20 billion per year [16].

To sum up, rational spatial management is one of the most underrated endogenous growth impulses of economy in Poland. The high amounts of financial turnover related to implementing spatial plans, when related to many communes' budgets, indicate that spatial planning could be a driving force for local economies. Meanwhile, in many cases, due to negative balances, it threatens to destabilize public finances.

In conclusion, it can be said that for local politics and local law, compared to other countries, the Polish model has not proved successful, as it gives too much freedom in determining income and costs as well as the methods of obtaining and spending them, and thus generating not profits, but mostly losses. In this respect, the presented research provides an illustrative and symptomatic lesson for other countries on how not to proceed in spatial planning on real estate markets.

Author Contributions: Conceptualization, P.Ś. and M.N.; methodology, P.Ś.; software, M.B.; validation, M.B. and M.N.; formal analysis, P.Ś. and M.N.; investigation, P.Ś., M.N., P.S. and M.Z.; resources, P.Ś. and P.S.; data curation, P.Ś. and P.S.; writing-original draft preparation, M.N., P.Ś., P.S. and M.Z.; writing-review and editing, M.N. and P.Ś; visualization, P.Ś., P.S. and M.B.; supervision, M.N.; project administration, P.Ś. and M.N.; funding acquisition, P.Ś. All authors have read and agreed to the published version of the manuscript.

Funding: This research received no external funding.

Institutional Review Board Statement: Not applicable.

Informed Consent Statement: Not applicable.

Conflicts of Interest: The authors declare no conflict of interest. 


\section{References}

1. Dühr, S.; Colomb, C.; Nadin, V. (Eds.) European Spatial Planning and Territorial Cooperation; Routledge: London, UK; New York, NY, USA, 2010; pp. 360-371, ISBN 978-0-415-46774-2.

2. Bogetoft, P.; Pruzan, P. Planning with Multiple Criteria: Investigation, Communication and Choice; Elsevier Science Pub.: Amsterdam, The Netherlands, 1991; pp. 117-123, ISBN 044488999X.

3. De Groot, R. Function-analysis and valuation as a tool to assess land use conflicts in planning for sustainable, multi-functional landscapes. Landsc. Urban Plan. 2006, 75, 175-186. [CrossRef]

4. Pacione, M. Private profit, public interest and land use planning-A conflict interpretation of residential development pressure in Glasgow's rural-urban fringe. Land Use Policy 2013, 32, 61-77. [CrossRef]

5. Morrill, R.L.; Symons, J. Efficiency and equity aspects of optimum location. Geogr. Anal. 1977, 9, 215-225. [CrossRef]

6. Mäntysalo, R. Learning from the UK: Towards market-oriented land-use planning in Finland. Hous. Theory Soc. 1999, 16, 179-191. [CrossRef]

7. DeVerteuil, G. Reconsidering the legacy of urban public facility location theory in human geography. Prog. Hum. Geogr. 2000, 24, 47-69. [CrossRef]

8. Rajakallio, K.; Cuthbertson, R.; Pulkka, L.; Junnila, S. Creating urban platforms-Opportunities and challenges for innovation in commercial real estate development. Cities 2018, 77, 92-103. [CrossRef]

9. Rebelo, E.M. Land betterment capture revisited: A methodology for territorial plans. Land Use Policy 2017, 69, 392-407. [CrossRef]

10. Hopkins, L.D.; Knaap, G.J. Autonomous planning: Using plans as signals. Plan. Theory 2018, 17, 274-295. [CrossRef]

11. Immergluck, D. Large redevelopment initiatives, housing values and gentrification: The case of the Atlanta Beltline. Urban Stud. 2009, 46, 1723-1745. [CrossRef]

12. Cho, G.H.; Kim, J.H.; Lee, G. Announcement effects of urban regeneration plans on residential property values: Evidence from Ulsan, Korea. Cities 2020, 97. [CrossRef]

13. Nesticò, A.; Endreny, T.; Guarini, M.R.; Sica, F.; Anelli, D. Real Estate Values, Tree Cover, and Per-Capita Income: An Evaluation of the Interdependencies in Buffalo City (NY). In Proceedings of the International Conference on Computational Science and Its Applications, Cagliari, Italy, 1-4 July 2020; Springer: Cham, Switzerland; Amsterdam, The Netherlands, 2020 ; pp. 913-926.

14. Ehrlich, M.V.; Hilber, C.A.L.; Schöni, O. Institutional settings and urban masl: Evidence from Europe. J. Hous. Econ. Elsevier 2018, 42, 4-18. [CrossRef]

15. Debrunner, G.; Hartmann, T. Strategic use of land policy instruments for affordable housing-Coping with social challenges under scarce land conditions in Swiss cities. Land Use Policy 2020, 99, 104993. [CrossRef]

16. Śleszyński, P.; Kowalewski, A.; Markowski, T.; Legutko-Kobus, P.; Nowak, M. The Contemporary Economic Costs of Spatial Chaos: Evidence from Poland. Land 2020, 9, 214. [CrossRef]

17. Domański, R. Accessibility, Efficiency, and Spatial Organization. Environ. Plan. 1979, 11, 1189-1206. [CrossRef]

18. Pennington, D.N.; Dalzell, B.; Nelson, E.; Mulla, D.; Taff, S.; Hawthorne, P.; Polasky, S. Cost-effective land use planning: Optimizing land use and land management patterns to maximize social benefits. Ecol. Econ. 2017, 139, 75-90. [CrossRef]

19. Śleszyński, P.; Komornicki, T. Klasyfikacja funkcjonalna gmin Polski na potrzeby monitoringu planowania przestrzennego [Functional classification of Poland's communes (gminas) for the needs of the monitoring of spatial planning]. Przeglad Geogr. 2016, 88, 469-488. [CrossRef]

20. Reimer, M.; Getimis, P.; Blotevogel, H. Spatial planning systems and practices in Europe: A comparative perspective. In Spatial Planning Systems and Practices in Europe. A Comparative Perspective on Continuity and Changes; Reimer, M., Getimis, P., Blotevogel, H., Eds.; Routledge: New York, NY, USA, 2014; pp. 170-176, ISBN 9780415727242.

21. Nadin, V.; Stead, D. European spatial planning systems, social, models and learning. Disp Plan. Rev. 2008, 44, 35-47. [CrossRef]

22. Nadin, V. International comparative planning methodology: Introduction to the theme issue. Plan. Pract. Res. 2012, 27, 1-5. [CrossRef]

23. Reimer, M.; Blotevogel, H. Comparing spatial practice in Europe: A plea for cultural sensitization. Plan. Pract. Res. 2012, 27, 7-24. [CrossRef]

24. Berisha, E.; Cotella, G.; Janin-Rivolin, U.; Solly, A. Spatial governance and planning systems and the public control of spatial development: A European typology. Eur. Plan. Stud. 2020, 29, 181-200. [CrossRef]

25. Lindholm, G. Land and Ladscape; Linking Use, Experience and Property Development in Urban Areas. Land 2019, 8, 137. [CrossRef]

26. Levačić, R. Markets and government: An overview. In Markets, Hierarchies and Networks: The Coordination of Social Life; Thompson, G., Frances, J., Levačić, R., Mitchel, J., Eds.; SAGE: London, UK, 1991; pp. 35-47, ISBN 978-0803985902.

27. Wolf, C. Markets or Governments: Choosing between Imperfect Alternatives, 2nd ed.; MIT Press: Cambridge, MA, USA, 1993; pp. 140-151, ISBN 9780262231725.

28. Webster, C.J. Public choice, Pigouvian and Coasian planning theory. Urban Stud. 1998, 35, 53-75. [CrossRef]

29. Bertaud, A.; Malpezzi, S. Measuring the costs and benefits of urban land use regulation: A simple model with an application to Malaysia. J. Hous. Econ. 2001, 10, 393-418. [CrossRef]

30. Brueckner, J.K. Government land use interventions: An economic analysis. In Urban Land Markets: Improving Land Management for Successful Urbanization; Lall, S.V., Freire, M., Yuen, B., Eds.; Springer: Dordrecht, The Netherlands, 2009; pp. 3-23, ISBN 978-1-4020-8862-9. 
31. Alterman, R. Takings International: A Cross-National. In Takings International. A comparative Perspective on Land Use Regulations and Compensation Rights; Alterman, R., Ed.; American Bar Association: Chicago, IL, USA, 2010; pp. 1-75, ISBN 978-1-60442-550-5.

32. Majewska, A.; Denis, M.; Krupowicz, W. Urbanization Chaos of Suburban Small Cities in Poland: 'Tetris Development'. Land 2020, 9, 461. [CrossRef]

33. Glaeser, E.L.; Ward, B.A. The causes and consequences of land use regulation: Evidence from Greater Boston. J. Urban Econ. 2009, 65, 265-278. [CrossRef]

34. Kok, N.; Monkkonen, P.; Quigley, J.M. Land use regulations and the value of land and housing: An intra-metropolitan analysis. J. Urban Econ. 2014, 81, 136-148. [CrossRef]

35. Irwin, E.G.; Bockstael, N.E. The problem of identifying land use spillovers: Measuring the effects of open space on residential property values. Am. J. Agric. Econ. 2001, 83, 698-704. [CrossRef]

36. Anderson, S.T.; West, S.E. Open space, residential property values, and spatial context. Reg. Sci. Urban Econ. 2006, 36, 773-789. [CrossRef]

37. Morano, P.; Guarini, M.R.; Tajani, F.; Di Liddo, F.; Anelli, D. Incidence of Different Types of Urban Green Spaces on Property Prices. A Case Study in the Flaminio District of Rome (Italy). In Proceedings of the 19th International Conference on Computional Science and Its Applications (ICCSA 2019), Saint Petersburg, Russia, 1-4 July 2019; pp. 23-34.

38. European Commission. The EU Compendium of Spatial Planning Systems and Policies; Regional Development Studies; European Commission: Brussels, Belgium, 1997; Volume 28, pp. 47-80.

39. Newman, P.; Thornley, A. Urban Planning in Europe. International Competition, National Systems and Planning Projects, 1st ed.; Routledge: London, UK; New York, NY, USA, 1996; pp. 28-41, ISBN 9780415111799.

40. Janin-Riviolin, U.; Faludi, A. The hidden face of European spatial planning: Innovations in governance. Eur. Plann. Stud. 2005, 13, 195-215. [CrossRef]

41. Larsson, G. Spatial Planning Systems in Western Europe: An Overview; IOS Press: Amsterdam, The Netherlands, 2006; pp. 21-49, ISBN 978-1-58603-656-0.

42. Stein, L. Comparative Urban Land Use Planning: Best Practice; Sydney University Press: Sydney, Austria, 2017; pp. 330-337, ISBN 9781743324677.

43. Muñoz-Gielen, D.; Tasan Kok, T. Flexibility in planning and the consequences for public value capturing in UK, Spain and the Netherlands. Eur. Plan. Stud. 2010, 18, 1097-1131. [CrossRef]

44. Nadin, V.; Stead, D. Spatial planning in the United Kingdom 1990-2013. In Spatial Planning Systems and Practices in Europe: A Comparative Perspective on Continuity and Changes; Reimer, M., Getimis, P., Blotevogel, H., Eds.; Routledge: New York, NY, USA, 2014; pp. 198-214, ISBN 9780415727242.

45. von Schumacher, J.; Werk, K. Raumordnungsgesetz, Kommentar; Kommunal—und Schul-Verlag: Wiesbaden, Germany, 2012; ISBN 3829308571.

46. Geppert, A. Vae Victis! Spatial planning in the rescaled metropolitan governance in France. Raumforsch. Und Raumordn. Spat. Res. Plan. 2017, 75, 225-241. [CrossRef]

47. Geppert, A. France, drifting away from the "regional economic" approach. In Spatial Planning Systems and Practices in Europe; Routledge: London, UK; pp. 129-146, ISBN 9781315852577.

48. Blotevogel, H.; Danielzyk, R.; Münter, A. Spatial planning in Germany: Institutional inertia and new challenges. In Spatial Planning Systems and Practices in Europe: A Comparative Perspective on Continuity and Changes; Reimer, M., Getimis, P., Blotevogel, H., Eds.; Routledge: New York, NY, USA, 2014; pp. 77-101, ISBN 9780415727242.

49. Muñoz-Gielen, D. Urban governance, property rights, land readjustment and public value capturing. Eur. Urban Reg. Stud. 2014, 21, 60-78. [CrossRef]

50. Alterman, R. Land use regulations and property values: The "Windfalls Capture" Idea Revisited. In The Oxford Handbook of Urban Economics and Planning; Brooks, N., Donaghy, K., Knaap, G.J., Eds.; Oxford University Press: Oxford, UK, 2012; pp. 755-786, ISBN 978-0-19-53-8062-0. Available online: https:/ / papers.ssrn.com/sol3/papers.cfm?abstract_id=2309571 (accessed on 10 December 2020).

51. Muñoz-Gielen, D.; Salas, I.M.; Cuadrado, J.B. International comparison of the changing dynamics of governance approaches to land development and their results for public value capture. Cities 2017, 71, 123-134. [CrossRef]

52. Suzuki, H.; Murakami, J.; Hong, Y.H.; Tamayose, B. Financing Transit-Oriented Development with Land Values: Adapting Land Value Capture in Developing Countries; The World Bank: Washington, DC, USA, 2015; pp. 37-39, 45-46, ISBN 978-1-4648-0149-5.

53. Kim, M. Upzoning and value capture: How US local governments use land use regulation power to create and capture value from real estate developments. Land Use Policy 2020, 95, 104624. [CrossRef]

54. Van der Veen, M.; Spaans, M.; Janssen-Jansen, L. Using compensation instruments as a vehicle to improve spatial planning: Challenges and opportunities. Land Use Policy 2010, 27, 1010-1017. [CrossRef]

55. Colavitti, A.M.; Serra, S. Non financial compensation for the redevelopment of the historic urban landscape: The case study of Villasor in Sardinia (Italy). City Territ. Archit. 2020, 7, 1-15. [CrossRef]

56. Machemer, P.L.; Kaplowitz, M.D. A Framework for evaluating transferable development rights programmes. J. Environ. Plan. Manag. 2002, 45, 773-795. [CrossRef]

57. Goldman, M. Speculative urbanism and the making of the next world city. Int. J. Urban Reg. Res. 2011, 35, 555-581. [CrossRef]

58. Flechner, H.L. Land Banking in the Control of Urban Development; Praeger Publishers: New York, NY, USA, 1974; pp. 45-52. 
59. Van Dijk, T.; Kopeva, D. Land banking and Central Europe: Future relevance, current initiatives, Western European past experience. Land Use Policy 2006, 23, 286-301. [CrossRef]

60. Węcławowicz, G. Contemporary Poland; Space and Society; UCL Press: London, UK, 1996.

61. Nadin, V.; Fernández Maldonado, A.; Zonneveld, W.; Stead, D.; Dąbrowski, M.; Piskorek, K.; Sarkar, A.; Schmitt, P.; Smas, L.; Cotella, G.; et al. COMPASS—Comparative Analysis of Territorial Governance and Spatial Planning Systems in Europe Applied Research 2016-2018 Final Report; ESPON: Luxembourg, 2018; Available online: https:/ / www.espon.eu/planning-systems (accessed on 10 December 2020).

62. Alrock, U.; Guntner, S.; Huning, S.; Peters, D. Spatial Planning and Urban Development in the New EU Member States-Between Adjustment anf Reinvention. In Spatial Planning and Urban Development in the New EU Members States; From Adjustment to Reinvention; Alrock, U., Gunter, S., Huning, S., Peters, D., Eds.; Routledge: London, UK; New York, NY, USA, 2016; pp. 1-18, ISBN 9781138273214.

63. Maier, K. Changing Planning in the Czech Republic. In Spatial Planning Systems and Practices in Europe; Routledge: London, UK, 2014; pp. 215-235, ISBN 9780415727235.

64. Kowalewski, A.; Markowski, T.; Śleszyński, P. Studia nad Chaosem Przestrzennym, Tom III: Synteza; Uwarunkowania, skutki i propozycje naprawy chaosu, Studia KPZK PAN: Warszawa, Poland, 2018; Volume 182. Available online: http://journals.pan.pl/ skpzk/125269 (accessed on 10 December 2020).

65. Gorzym-Wilkowski, W. Spatial Planning as a Tool for Sustainable Development. Polish Realities. Barom. Reg. 2017, 15, 75-85. Available online: http://br.wszia.edu.pl/zeszyty/pdfs/br48_07gorzym.pdf (accessed on 10 December 2020).

66. Parysek, J.J. Asking about the future of spatial management in Poland (thirteen years on from the 2003 legal regulation). Ruch Praw. Ekon. I Socjol. 2016, 78, 37-58. [CrossRef]

67. Kowalewski, A.; Mordasewicz, J.; Osiatyński, J.; Regulski, J.; Stępień, J.; Śleszyński, P. Raport o Ekonomicznych Stratach i Społecznych Kosztach Niekontrolowanej Urbanizacji w Polsce; Fundacja Rozwoju Demokracji Lokalnej, IGiPZ PAN: Warszawa, Poland, 2013; pp. 4-6. Available online: http:/ /obserwatorium.miasta.pl/wp-content/uploads/2016/08/Raport-Ekonomiczny-29.10.2013 -calosc.pdf (accessed on 10 December 2020).

68. Nowak, M. The Stakeholders and Municipal Authorities in the Spatial Competition. Biul. Kpzk Pan 2017, 265, 22-35. Available online: http:/ /journals.pan.pl/Content/100772/PDF/Biuletyn+KPZK+265+3-M.Nowak.pdf?handler=pdf (accessed on 10 December 2020).

69. Mickiewicz, P.; Nowak, M. Environmental protection and integrated development planning in local spatial policy on the example of Poland. Ann. Univ. Apulensis Ser. Oeconomica 2020, 22, 11-18. [CrossRef]

70. Śleszyński, P.; Gibas, P.; Sudra, P. The problem of mismatch between the CORINE Land Cover data classification and the development of settlement in Poland. Remote Sens. 2020, 12, 2253. [CrossRef]

71. Swianiewicz, P. Local Government Borrowing: Risks and Rewards: A Reporton Central and Eastern Europe; Local Government and Public Service Reform Initiative, Open Society Institute: Budapest, Hungary, 2004; p. 427.

72. Szarowská, I.; Majerová, I.; Šebestová, J. Indicators of financial stability for needs of municipalities [Indikátory finanční stability pro potřeby obcí]. Český Finanční Účetní Časopis 2018, 1, 25-45. [CrossRef]

73. Ushakova, E.; Pak, H.; Kuprin, A. Problems of assessing the financial stability and security of municipalities. Matec Web Conf. 2018, 170, 2. [CrossRef]

74. Aleksandrova-Zlatanska, S.K. Evaluating the factors for fiscal stability of rural municipalities: The case of Bulgaria, Problems of Agricultural Economics. Zagadnienia Ekon. Rolnej/Probl. Agric. Econ. 2019, 360, 156-170. [CrossRef]

75. Górczyńska, M.; Śleszyński, P.; Niedzielski, M. Impact of property rights and ownership on the development of Warsaw's contemporary city centre. Eur. Plan. Stud. 2019, 27, 160-180. [CrossRef]

76. Dixit, A.K. The Making of Economic Policy: A Transaction-Cost Politics Perspective; MIT Press: Cambridge, MA, USA, 1998; pp. 200-206, ISBN 9780262041553.

77. Jacobs, H.M. The Future of the Regulatory Takings Issue in the United States and Europe: Divergence or Convergence? Urban Lawyer 2008, 40, 52-72. Available online: https: / / www.harveymjacobs.com/wp-content/uploads/2018/06/Jacobs-2008 -Regulatory-Takings-Urban-Lawyer.pdf (accessed on 21 December 2020).

78. Muñoz-Gielen, D. Improving Public-Value Capturing in Urban Development. In Innovative Land and Property Taxation; Sietchiping, R., Ed.; United Nations Human Settlements Programme (UN-Habitat): Nairobi, Kenya, 2011; pp. 148-169, ISBN 978-92-1-132407-5.

79. Nowak, M. Niesprawność władz publicznych a polityka przestrzenna w Polsce. Zarzadzanie Publiczne 2016, 2, 94-106. Available online: http:/ / bazhum.muzhp.pl/media / / files/Zarzadzanie_Publiczne/Zarzadzanie_Publiczne-r2016-t-n36_(2)/Zarzadzanie_ Publiczne-r2016-t-n36_(2)-s94-106/Zarzadzanie_Publiczne-r2016-t-n36_(2)-s94-106.pdf (accessed on 10 December 2020). [CrossRef] 